\title{
Physicochemical characterization of some multifloral honeys from honeybees Apis mellifera collected in the Algerian northeast
}

\author{
Assia Amri* and Ali Ladjama \\ Department of Biochemistry, Faculty of Sciences, University of Annaba, BP 12 - 23000 - Annaba, Algeria. \\ Accepted 4 June, 2013
}

\begin{abstract}
The characterization of some Algerian northeast honey was carried out on the basis of their physicochemical properties: moisture, hydroxymethylfurfural, diastase activity, $\mathrm{pH}$, free, total and lactonic acidity, electrical conductivity, mineral and proline content. Studied samples are found to be low in moisture and therefore safe from fermentation, low in HMF level and high in diastase activity. Additionally, the diastase activity and the HMF content are widely recognized parameters indicating the freshness of honey. The quality of honey samples differs on account of various factors such as season, packaging and processing conditions, floral source, geographical origin and storage period. It is important that precautions should be taken to ensure standardization and rationalization of beekeeping techniques, manufacturing procedures and storing processes to improve honey quality.
\end{abstract}

Key words: Honey, physico-chemical characterisation, HMF, diastase activity.

\section{INTRODUCTION}

Honey is a very important energy food and is used as an ingredient in hundreds of manufactured foods, particularly in cereal-based products, for its sweetness, colour, flavour, caramelisation and viscosity (Rodrigez and Ferrer, 2004). The composition of honey depends on the plant species visited by the honeybees and the environmental, processing and storage conditions (Bertoncelj et al., 2007; Guler et al., 2007). Honey produced by the honeybee is a natural super saturated sugar solution, which is mainly composed of a complex mixture of carbohydrates. In addition, to carbohydrates, it also contains certain minor constituents, including proteins, enzymes (invertase, glucose oxidase, catalase, phosphatases), amino and organic acids (gluconic and acetic acids), lipids, vitamins (ascorbic acid, niacin, pyridoxine), volatile chemicals, phenolic acids, flavonoids and carotenoid-like substances and minerals (Blasa et al., 2006). Fresh honey is usually heated in order to faci- litate processing and to maintain good quality. However, excessive heat treatment leads to the formation of hydroxymethylfurfural (HMF) and reduced honey quality. HMF value is virtually absent or very low in fresh honey and is high in honey that has been heated, stored in inadequate conditions, or adulterated with invert syrup (Nozal et al., 2001). Chemical properties of honey such as $\mathrm{pH}$, mineral content and total acidity also affect HMF content. The presence of organic acids and low water activity also favours the production of HMF (Kalabova et al., 2003). The Codex Alimentarius (2001) and International Honey Commission (2002) set the maximum concentration of HMF to $40 \mathrm{mg} / \mathrm{kg}$ for honey from nontropical regions and $80 \mathrm{mg} / \mathrm{kg}$ for honey from tropical regions.

Extremely high (>500 mg/kg) HMF values demonstrate adulteration with invert syrup (Coco et al., 1996). There is a vast number of floral species characteristic of Algeria 


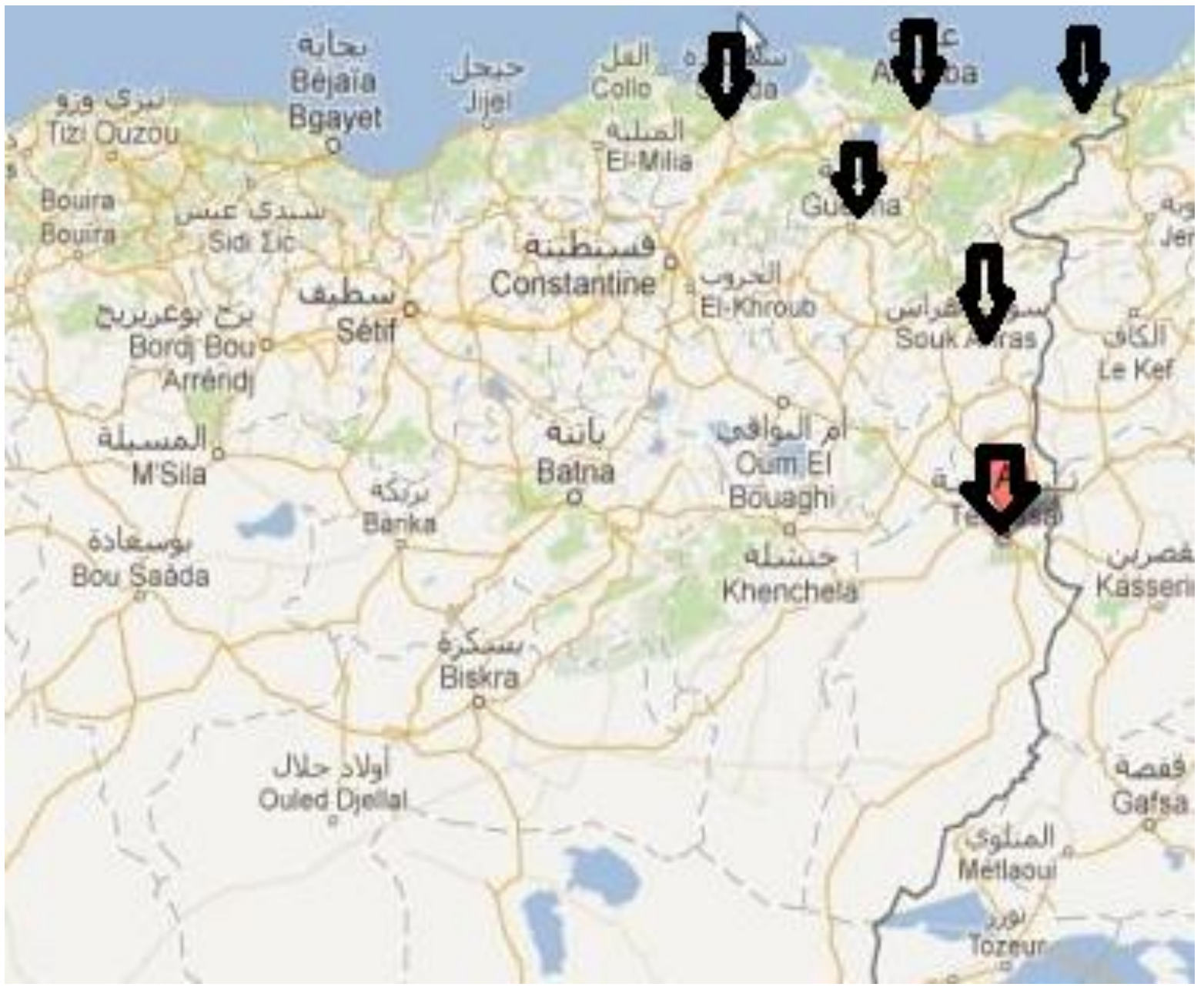

Figure1: Maps of the geographical origin of the honey samples.

visited by the honeybees. However, reports of the chemical composition of Algerian honeys are scarce (Makhloufi et al., 2007; Ouchemoukh et al., 2007). The potential honey production is very high in the Algerian northeast; this is related to the botanical wealth and the biodiversity of this region. Therefore, this study was carried out to evaluate the physicochemical quality of twenty Algerian Northeast honey samples from Apis mellifera.

\section{MATERIALS AND METHODS}

\section{Honey samples}

Twenty blossom honeys from various regions of Algerian Northeast were used. The samples of honey collected from bee-keepers were classified according to their botanical origin using the method established by the International Commission of Bee Botany described by Louveaux et al. (1978). The result shows that all samples are multifloral honey (no dominant pollen) with the presence of Secondary pollen (16 to 45\%): Trifolium sp, Eucalyptus, Hedysarium coronarium, Echium and Rosaceae. Minor pollen (3 to 15\%): Prunus / Pyrus, Fabaceae, Carduus and Erica arborea. Pollen very minor or isolated ( $<3 \%)$ : Allium spp, Apiaceae, Lavandula asphodelus, Lavandula stoechas, Lamiaceae, Brassicaceae, Taraxacum, Euphorbiaceae, Rhamnaceae, Asteraceae, Prunus / Pyrus, Mimosa pudica, Helianthus, mimosa bimucromata, Arctium and $X$ (indeterminate species). All the samples were collected in six different region of Northeast Algeria during the years 2004 to 2007 (Figure 1 and Table 1).

\section{Physico-chemical analysis}

Water content was determined by refractometry, $\mathrm{pH}$ was assessed in a $10 \%(\mathrm{w} / \mathrm{v})$, total acidity, free acid, lactone and proline contents were measured in fresh honey samples using AOAC methods (Helrich, 1990). Proline content was determined by the measurement of the absorbance at $510 \mathrm{~nm}$ of the resulting product between proline and ninhydrin. Mineral content and electrical conductivity were determined by the methods of Bogdanov et al. (1997). Ash content was determined by heating $5 \mathrm{~g}$ of honey at $625^{\circ} \mathrm{C}$ in a muffle furnace. Electrical conductivity was measured in a $20 \%(\mathrm{w} / \mathrm{v})$ solution of honey. The protein content was determined by the method of Bradford (1976), the quantity of proteins was estimated at $595 \mathrm{~nm}$ in relation to bovine serum albumin standard. HMF and diastase activity were measured as recommended by the 
Table 1. Botanical and geographical origins of honey samples

\begin{tabular}{llll}
\hline Samples & Botanical origin & Geographic origin & Year collected \\
\hline S1 & multifloral & El taref & 2006 \\
S2 & multifloral & Tebessa & 2007 \\
S3 & multifloral & Tebessa & 2007 \\
S4 & multifloral & El taref & 2007 \\
S5 & multifloral & Annaba & 2007 \\
S6 & multifloral & El taref & 2004 \\
S7 & multifloral & Annaba & 2004 \\
S8 & multifloral & El taref & 2004 \\
S9 & multifloral & Skikda & 2004 \\
S10 & multifloral & Skikda & 2004 \\
S11 & multifloral & El taref & 2004 \\
S12 & multifloral & SoukAhras & 2004 \\
S13 & multifloral & Tebessa & 2004 \\
S14 & multifloral & Guelma & 2004 \\
S15 & multifloral & SoukAhras & 2004 \\
S16 & multifloral & Annaba & 2005 \\
S17 & multifloral & Guelma & 2005 \\
S18 & multifloral & SoukAhras & 2005 \\
S19 & multifloral & Tebessa & 2006 \\
S20 & multifloral & Annaba & 2006 \\
\hline
\end{tabular}

Codex Alimentarius Commission (CAC, 1989).

\section{RESULTS}

Table 2 shows the mean values, standard deviations and ranges of the data of the different physico-chemical parameter analyses. The parameters indicating product maturity had values that fell into the limits set by current European Community requirements.

\section{DISCUSSION}

\section{Moisture content}

The moisture content in the investigated samples ranged from 13.7 to $18.09 \%$ (Table 2). All tested Algerian honeys had moisture content below $20 \%$, which is the maximum prescribed limit for the moisture content as per the Codex standard for honey (Codex Alimentarius, 2001). The different moisture content of honey depends on harvest season, the degree of maturity reached in the hive and moisture content of the plant nectar source (Finola et al., 2007).

\section{pH}

The $\mathrm{pH}$ values of honey are of great importance during extraction and storage, since acidity can influence the texture, stability and shelf life of honey (Terrab et al.,
2003). All honeys are acidic, having a $\mathrm{pH}$ in the range of 3.33 to 4.6 (Table 2). The acidity of honey is due to the presence of organic acids, particularly gluconic acid; and inorganic ions such as phosphate and chloride (Nanda et al., 2003). These results agreed with data reported by Azeredo et al. (2003). In general, honey is acidic in nature irrespective of its variable geographical origins. The $\mathrm{pH}$ values of Algerian, Brazilian, Spanish, Turkish and Indian honeys have been found to vary between 3.49 to $4.53,3.10$ to $4.05,3.63$ to $5.01,3.67$ to 4.57 and 3.49 to 4.43, respectively (Azeredo et al., 2003; Ouchemoukh et al., 2007; Kayacier and Karaman, 2008; Sudhanshu et al., 2010).

\section{Free acidity of honeys}

Free acidity of all twenty samples fell within the permitted range proposed by Codex Alimentarius (2001) of not more than 50 milliequiv acid $/ \mathrm{kg}$. The free acidity of honey samples in this study ranged from 25.763 to 44.884 milliequiv acid/kg (Table 2).

\section{Lactonic acidity of honeys}

Lactonic acidity of the honey ranged from 7.063 to 10.9 milliequiv acid/kg (Table 2).

\section{Total acidity of honeys}

Total acidity of the honey ranged from 34.363 to 54.317 
Table 2. Physico-chemical characteristics of some Algerian honey samples.

\begin{tabular}{|c|c|c|c|c|c|c|c|c|c|c|}
\hline Samples & Moisture \% & $\mathrm{pH}$ & $\begin{array}{l}\text { Electric } \\
\text { Conductivity } \\
(\mu \mathrm{s} / \mathrm{cm})\end{array}$ & $\begin{array}{c}\text { Mineral } \\
\text { content } \%\end{array}$ & $\begin{array}{l}\text { Free acidity } \\
\text { (meq/Kg) }\end{array}$ & $\begin{array}{l}\text { Lactonic acidity } \\
\quad(\mathrm{meq} / \mathrm{Kg})\end{array}$ & $\begin{array}{l}\text { Total acidity } \\
\text { (meq/Kg) }\end{array}$ & $\begin{array}{c}\text { HMF } \\
(\mathrm{mg} / \mathrm{Kg})\end{array}$ & $\begin{array}{c}\text { DN } \\
\text { Schade unite }\end{array}$ & $\begin{array}{l}\text { Proline conten } \\
\mathrm{mg} / \mathrm{Kg}\end{array}$ \\
\hline S1 & $15.4 \pm 0.23$ & $4.4 \pm 0.02$ & $309 \pm 1$ & $0.128 \pm 0.001$ & $25.763 \pm 0.37$ & $8.6 \pm 0.01$ & $34.363 \pm 0.38$ & $4.1 \pm 0.45$ & $198.0 \pm 0.45$ & $454.3 \pm 0.01$ \\
\hline S2 & $13.8 \pm 0.453$ & $4.6 \pm 0.03$ & $686 \pm 2$ & $0.441 \pm 0.084$ & $28.098 \pm 0.05$ & $9.073 \pm 0.4$ & $37.171 \pm 0.45$ & $9.7 \pm 1.15$ & $117.23 \pm 0.12$ & $110.7 \pm 0.52$ \\
\hline S3 & $14.1 \pm 0.125$ & $4.1 \pm 0.03$ & $314 \pm 2$ & $0.35 \pm 0.067$ & $41.231 \pm 0.50$ & $10.9 \pm 0.75$ & $52.131 \pm 1.25$ & $10.3 \pm 0.16$ & $100.33 \pm 2.67$ & $100 \pm 0.388$ \\
\hline S4 & $17.7 \pm 0.651$ & $4.1 \pm 0.035$ & $1050.5 \pm 1.5$ & $0.518 \pm 0.013$ & $32.7 \pm 0.35$ & $7.983 \pm 0.00$ & $40.683 \pm 0.35$ & $7.4 \pm 0.91$ & $154.1 \pm 2.11$ & $364 \pm 0.632$ \\
\hline S5 & $13.7 \pm 0.587$ & $4.4 \pm 0.023$ & $326.5 \pm 0.5$ & $0.111 \pm 0.054$ & $35.7 \pm 0.18$ & $10.873 \pm 0.50$ & $46.573 \pm 0.68$ & $4.0 \pm 0.33$ & $202.123 \pm 3.56$ & $502.5 \pm 0.752$ \\
\hline S6 & $15.21 \pm 0.685$ & $3.33 \pm 0.351$ & $349 \pm 5.13$ & $0,37 \pm 0.036$ & $29.9 \pm 1.00$ & $7.063 \pm 1.00$ & $36.963 \pm 2$ & $10.217 \pm 0.529$ & $44.45 \pm 4.0$ & $403.36 \pm 0.557$ \\
\hline S7 & $16.63 \pm 0.34$ & $4.027 \pm 0.006$ & $499.5 \pm 1.5$ & $0,44 \pm 0.095$ & $44.884 \pm 2.517$ & $9.10 \pm 0.90$ & $54.317 \pm 1.303$ & $11.26 \pm 0.276$ & $51.82 \pm 4.06$ & $305.67 \pm 0.58$ \\
\hline S8 & $16.18 \pm 0.16$ & $3.47 \pm 0.334$ & $269.33 \pm 1.15$ & $0,233 \pm 0.030$ & $28.023 \pm 0.70$ & $8.0 \pm 1.05$ & $36.02 \pm 1.75$ & $1.12 \pm 0.11$ & $94.23 \pm 3.6$ & $407.593 \pm 0.713$ \\
\hline S9 & $17.177 \pm 0.26$ & $3.8 \pm 0.025$ & $312.67 \pm 1.15$ & $0,283 \pm 0.015$ & $27.02 \pm 2.00$ & $10.02 \pm 0.02$ & $37.04 \pm 2.02$ & $2.115 \pm 0.094$ & $105.63 \pm 4.41$ & $203.99 \pm 0.165$ \\
\hline S10 & $17.14 \pm 0.140$ & $3.5 \pm 0.055$ & $286 \pm 2.00$ & $0,263 \pm 0.032$ & $33.3 \pm 1.00$ & $10.067 \pm 1.017$ & $43.367 \pm 2.017$ & $7.276 \pm 0.216$ & $76.85 \pm 1.61$ & $201.133 \pm 1.0$ \\
\hline S11 & $16.243 \pm 0.084$ & $4.34 \pm 0.270$ & $147.97 \pm 0.55$ & $0,11 \pm 0.01$ & $40.0 \pm 0.481$ & $10.38 \pm 1.00$ & $50.38 \pm 1.481$ & $4.483 \pm 0.379$ & $83.81 \pm 4.81$ & $206.98 \pm 0.076$ \\
\hline $\mathrm{S} 12$ & $15.043 \pm 1.092$ & $4.2 \pm 0.396$ & $266.67 \pm 9.02$ & $0,213 \pm 0.020$ & $31.68 \pm 1.87$ & $11.033 \pm 1$ & $42.713 \pm 2.87$ & $6.217 \pm 0.758$ & $86.08 \pm 4.01$ & $506.86 \pm 1.091$ \\
\hline S13 & $15.633 \pm 1.041$ & $4.0 \pm 0.215$ & $307 \pm 1.07$ & $0,363 \pm 0.028$ & $42.033 \pm 0.475$ & $9 \pm 1.50$ & $51.033 \pm 1.975$ & $3.747 \pm 0.357$ & $76.96 \pm 4.95$ & $309.5 \pm 0.608$ \\
\hline
\end{tabular}


Table 2. Contd

\begin{tabular}{|c|c|c|c|c|c|c|c|c|c|c|}
\hline S14 & $16.07 \pm 0.113$ & $3.84 \pm 0.064$ & $328.83 \pm 3.69$ & $0,234 \pm 0.173$ & $27.5 \pm 0.5$ & $9.5 \pm 0.5$ & $37 \pm 1.00$ & $14.153 \pm 0.055$ & $29.28 \pm 1.95$ & $156.167 \pm 1.258$ \\
\hline S15 & $18.09 \pm 0.131$ & $4.05 \pm 0.055$ & $67.83 \pm 2.57$ & $0,019 \pm 0.001$ & $35.3 \pm 0.20$ & $8.033 \pm 1.32$ & $43.333 \pm 1.52$ & $8.599 \pm 1.678$ & $43.67 \pm 1.10$ & $104.56 \pm 0.833$ \\
\hline S16 & $15.81 \pm 0.685$ & $3.45 \pm 0.151$ & $449 \pm 1.13$ & $0,27 \pm 0.006$ & $28.9 \pm 1.0 .11$ & $8.063 \pm 0.00$ & $36.963 \pm 0.11$ & $5.217 \pm 0.629$ & $54.45 \pm 3.0$ & $303.3 \pm 0.56$ \\
\hline $\mathrm{S} 17$ & $16.633 \pm 0.349$ & $4.02 \pm 0.001$ & $599.5 \pm 1.0$ & $0,45 \pm 0.015$ & $44.884 \pm 0.193$ & $9.10 \pm 0.40$ & $54.317 \pm 0.59$ & $11.0 \pm 0.176$ & $52.82 \pm 4.06$ & $405.67 \pm 0.5$ \\
\hline S18 & $17.18 \pm 0.101$ & $4.47 \pm 0.134$ & $369.33 \pm 0.15$ & $0,238 \pm 0.003$ & $27.023 \pm 0.485$ & $9.0 \pm 1.5$ & $36.02 \pm 1.985$ & $1.12 \pm 0.117$ & $95.23 \pm 2.6$ & $307.003 \pm 0.813$ \\
\hline S19 & $16.17 \pm 0.164$ & $3.91 \pm 0.125$ & $412.67 \pm 1.25$ & $0,383 \pm 0.015$ & $28.02 \pm .00$ & $9.02 \pm 2.02$ & $37.04 \pm 2.02$ & $1.11 \pm 0.004$ & $100.3 \pm 0.41$ & $103.99 \pm 0.275$ \\
\hline $\mathrm{S} 20$ & $16.14 \pm 0.150$ & $4.50 \pm 0.055$ & $487 \pm 2.00$ & $0.283 \pm 0.012$ & $38.3 \pm 2.420$ & $9.067 \pm 0.03$ & $43.367 \pm 2.25$ & $6.36 \pm 0.116$ & $76.00 \pm 1.61$ & $301.18 \pm 1.003$ \\
\hline
\end{tabular}

milliequiv acid $/ \mathrm{kg}$ (Table 2). The acidity of honey is due to the presence of organic acids, particularly gluconic acid, in equilibrium with their lactones or esters, and inorganic ions such as phosphate and chloride (El-Sherbiny and Rizk, 1979; Al-Khalifa and Al-Arify, 1999).

\section{Electrical conductivity of honeys}

The electrical conductivity as measured in most honeys is less than $700 \mu \mathrm{S} / \mathrm{cm}$ (Table 2). The sample S4 has the highest conductivity (1050.5 $\mu \mathrm{S} / \mathrm{cm})$. This parameter depends on the mineral, organic acid, protein, complex sugars and polyol content and varies with botanical origin (Terrab et al., 2003).

\section{Mineral content}

The mineral content of the honey ranged from
0.019 to $0.518 \%$ (Table 2). These differences in mineral content are dependent on the type of soil in which the original nectar bearing plant was located (Anklam, 1998).

The percentage mineral content is considered as a quality criterion indicating the possible botanical origin of honey. The variability in the mineral content of honeys could be due to harvesting processes, beekeeping techniques and the material collected by the bees while foraging on the flora (Finola et al., 2007).

\section{Proline content}

Proline comes mainly from the salivary secretions of $A$. mellifera during the conversion of nectar into honey (Bergner and Hahn, 1972). The concentrations of proline ranged between 103.66 and $506.86 \mathrm{mg} / \mathrm{kg}$ (Table 2).

\section{Amylase activity}

The amylase activity is usually expressed as diastase number, symbol DN, also known as Gothe units. The amylase activity ranged from 29.28 to 202.123 Gothe units (Table 2) and the remaining DN was still above the minimum limit $(8$ DN). Consequently, it has been recommended that other quality indicators, such as invertase activity, which is more heat-sensitive than amylase, should be used (Oddo et al., 1999).

\section{HMF content}

Since HMF can be formed either by Maillard reaction (heating of reducing sugars in the presence of proteins), or by dehydration under acidic conditions. The HMF values were low $(<15$ $\mathrm{mg} / \mathrm{kg}$ ) (Table 2). The diastase activity and the 
HMF content are widely recognized as parameters indicating the freshness of honey (Mendes et al., 1998; Terrab et al., 2002).

\section{Conclusion}

The result of this study indicated that honey samples purchased from Northeast Algeria, were mostly of good quality. The research describes the variability of some physicochemical characteristics of twenty Algerian honeys. The results obtained agreed with requirements of European Community Directive. Honey samples differ in quality on account of various factors such as season, the origin of honey, the activity of the bee, the food of the bee, the period and technique of extraction of honey, conditions of storage and the freshness of honey. The comparison of these honey varietals with published international standards allowed us to have an idea on the quality of our honeys produced in the Algerian Northeast.

\section{ACKNOWLEDGEMENT}

We are grateful to beekeepers that collaborated with us in providing honey samples.

\section{REFERENCES}

Al-Khalifa AS, Al-Arify IA (1999). Physicochemical characteristics and pollen spectrum of some Saudi honeys. Food Chem. 67:21-25.

Anklam E (1998). A review of the analytical methods to determine the geographical and botanical origin of honey. Food Chem. 63:549-563.

Azeredo LDC, Azeredo MAA, De Souza SR, Dutra VML (2003). Protein content and physicochemical properties in honey samples of Apis mellifera of different floral origins. Food Chem. 80:249-254.

Bergner KG, Hahn H (1972). Zum Vorkommen und zur Herkunft der freien Aminosa"uren in honig. Apidologie 3(1):5-34.

Bertoncelj J, Dobersek U, Jamnik M, Golob T (2007). Evaluation of the phenolic content, antioxidant activity and colour of Slovenian honey. Food Chem. 105:822-828.

Blasa M, Candiracci M, Accorsi A, Piacentini MP, Albertini MC, Piatti E (2006). Raw Millefiori honey is packed full of antioxidants. Food Chem. 97:217-222.

Bogdanov S (1997). Nature and origin of the antibacterial substances in honey. Lebensmittel Wissenchard und Technology 30:748-753.

Bradford MM (1976). A rapid and sensitive for the quantitation of microgram quantitites of protein utilizing the principle of protein-dye binding. Anal. Biochem. 72:248-254.

Coco FL, Valentini C, Novelli V, Ceccon L (1996). High-performance liquid chromatographic determination of 2-furaldehyde and 5hydroxymethyl-2-furaldehyde in honey. J. Chromatogr. A 95-102.

Codex Alimentarius Commission (1989). Codex standard for honey (worldwide standard). FAO-WHO, CAC Vol 3, Ed 1 Supp 2, Rome.

Codex Alimentarius Commission (2001). Revised codex standard for honey. Codex Standard 12-1981. Rome: FAO and WHO FOOD STANDARDS PROGRAMME.

El-Sherbiny GA, Rizk SS (1979). Chemical composition of both clovers and cotton honey produced in A.R.E Egypt. J. Food Sci. 7: 69-75.
Finola MS, Lasagno MC, Marioli JM (2007). Microbiological and chemical characterization of honeys from central Argentina. Food Chem. 100:1649-1653.

Guler A, Bakan A, Nisbet C, Yavuz O (2007). Determination of important biochemical properties of honey to discriminate pure and adulterated honey with sucrose (Saccharum officinarum L.) syrup. Food Chem. 105(111):9-1125.

Helrich K (1990). Oficial methods of analysis (15th ed.). Arlington, VA: Association of O?cial Analytical Chemists, Inc.

Kalabova K, Borkovcova I, Smutna M, Vecerek V (2003). Hydroxymethylfurfural in Czech honeys. Czechoslovak J. Anim. Sci. 48: 551-557.

Kayacier A, Karaman S (2008). Rheological and some physicochemical characteristics of selected Turkish honeys. J. Texture Studies 39:1727.

Louveaux J, Maurizio A, Vorwohl G (1978). Methods of melissopalynology. Bee World 59:139-157.

Makhloufi C, Schweitzer P, Azouzi B, Persano Oddo L, Choukri A, Laaredj $\mathrm{H}$ et al (2007) .Some properties of Algerian honeys. Apiacta 42:73-80.

Mendes E, Brojo PE, Ferreira IMPLVO, Ferreira MA (1998). Quality evaluation of Portuguese honey. Carbohydr. Polym. 37(3):219-223.

Nanda V, Sarkara BC, Sharma HK, Bawa ASV (2003). Physicochemical properties and estimation of mineral content in honey produced from different plants in Northern India. J. Food Composit. Anal.16:613-619.

Nozal MJ, Bernal JL, Toribio L, Jimenez JJ, Martin MT (2001) .Highperformance liquid chromatography determination of methylanthranilate, hydroxymethylfurfural and related compounds in honey. J. Chromatogr. A 917:95-103.

Oddo LP, Piazza MG, Pulcini P (1999). Invertase activity in honey. Apidologie 30:57-65.

Ouchemoukh S, Louaileche H, Schweitzer P (2007). Physicochemical characteristics and pollen spectrum of some Algerian honeys. Food Control 18:52-58.

Rodriguez GO, Ferrer BS, Ferrer A, Rodriguez B (2004). Characterization of honey produced in Venezuela. Food Chem. 84:499-502.

Sudhanshu S, Satyendra G, Arun S (2010) .Physical, biochemical and antioxidant properties of some Indian honeys. Food Chem.118: 391 397.

Terrab A, Diez MJ, Heredia FJ (2002). Characterization of Moroccan unifloral honeys by their physicochemical characteristics. Food Chem. 79:373-379.

Terrab A, Diez MJ, Heredia FJ (2003). Palynoloical, physico-chemical and colour characterization of Moroccan honeys: I. River red gum (Eucalyptus camaldulensis Dehnh) honey. Int. J. Food Sci. Technol. 38:379-386 